Journal of Engineering and Applied Sciences 14 (Special Issue 2): 5437-5442, 2019

ISSN: 1816-949X

(C) Medwell Journals, 2019

\title{
Accounting Conservatism and the Cost of Debt: Evidence from Iraq
}

\author{
${ }^{1}$ Rana Abdulamerr Mohammed, ${ }^{2}$ Ban Abdul Kadhm Abdulaali and ${ }^{2}$ Maytham Hazim Azeez Khuzaae \\ ${ }^{1}$ Department of Physical Education, College for Women \\ ${ }^{2}$ Department Public Health, College of Veterinary Medicine, University of Al-Qadisiyah, \\ Al-Diwaniyah, Al-Qadisiyah, Iraq \\ ali.daghir@yahoo.com
}

\begin{abstract}
The current study was focused on analyzing the tradeoff between Accounting Conservatism (AC) and the cost of debt by examining two relationships. The first relationship evaluates the effect of debtholders/shareholders conflicts on the level of unconditional AC represented in no N-Operating Accruals (NOA). The second relationship examines the effect of unconditional AC represented in NOA on the cost of debt. This study tried to examine these relationships using a sample of 122 firm year observations to the period 2016-2017 on the Iraq Stock Exchange. This study found positive relationship between AC and the debtholders/shareholders conflicts, i.e., increasing standard deviations of the return on assets as a proxy of operating uncertainty and dividends ratio leads to increase the NOA as a proxy for Unconditional Conservatism (UCC). In addition, found positive relationship between NOA and the cost of debt and negative relationship between firm size represented in total assets and the cost of debt, i.e., increasing the $\mathrm{AC}$ by minimizing the accruals leads to lower cost of debt and increasing total assets as guarantee for the creditors leads to lower cost of debt.
\end{abstract}

$\underline{\text { Key words: Conditional conservatism, UCC, cost of debt, NOA, relationship evaluates, stock exchange }}$

\section{INTRODUCTION}

$\mathrm{AC}$ is a prudential principle which is a much debated in recent years, It becomes more necessary when preparing financial statements under uncertainty about activity level (Watts, 2003). AC refers to choosing from, so, many choices which produces the lowest value of assets and net profit (Pae, 2007). It constrains the managerial opportunism which gives a positive signal to investors because of the increased level of care in recognizing profit (Watts, 2003; Ball, 2001; Ball and Shivakumar, 2005). This positive signal will increase stock price which leads to low level of information asymmetry (Rodrigues and Galdi, 2017).

There are two components of $\mathrm{AC}$; one of them is conditional which known as news-dependent and refers to the asymmetric response between bad and good news on earnings and means using accounting policies that recognize the effect of bad news on earnings faster than good news, so, Conditional Conservatism (CC) can be also called ex-post conservatism (Pae, 2007; Basu, 1997. 2005; Beaver and Ryan, 2005). The second one is unconditional which known as news independent, it refers to using accounting options resulting from accounting standards adoption for minimizing earnings without any bad news, so, it referred to balance-sheet conservatism and can be also called ex-ante conservatism (Beaver and Ryan, 2005).

$\mathrm{AC}$ has a lot of benefits which can be summarized in improving the efficiency of investments (Lara et al., 2016; Ahmed and Duellman, 2011) and lowing the cost of capital (Ahmed et al., 2002; Lara et al., 2011) because of facilitating access to external capital (Ahmed et al., 2002; Beatty et al., 2008). The early loss recognition is so, benefit for the debt holders by reducing dividends paid to shareholders which means the demand for conservatism stem from the contracting role related to the debt markets (Ball et al., 2008). In this way, AC moves control rights from shareholders to creditors (Ahmed and Duellman, 2011; Zhang, 2008; Francis and Martin, 2010),

Consequently, the only way for reducing risk to bondholder is increasing the level of $\mathrm{AC}$ which prevents paying excessive dividends to shareholders. As a result, risk reduction will be lead to lower interest rate paid for the bond holders in addition mitigating the bondholder-shareholder conflicts (Watts, 2003).

In this regard, Li (2015) argues that we can't deal with the negative relationship between $\mathrm{AC}$ and the cost

Corresponding Author: Rana Abdulamerr Mohammed, Department of Physical Education, College for Women, University of Al-Qadisiyah, Al-Diwaniyah, Al-Qadisiyah, Iraq, ali.daghir@yahoo.com 
of debt and the negative relationship between $\mathrm{AC}$ the bondholder-shareholder conflicts as a postulate because this relationship differ with the different countries by various institutional factors such as legal requirements, tax limitations, political and economic positions and market forces. As well as, this negative relationship only limited to the conditional conservatism. So, I can ask about the relationship direction between UCC and the cost of debt?

Consequently, based on the claim by Li (2015) I expect that Iraqi accounting environment good evidence for ensuring or denying the relationship direction between $\mathrm{AC}$ and the cost of debt and between $\mathrm{AC}$ and the bondholder-shareholder conflicts, especially, it ignores the debt financing. Moreover, based on my previous question about UCC I expect it is important to analyze this relationship in a different way by using UCC represented in NOA.

In brief, I can summarize the problem study in trying to answer this question: Is there a relationship between UCC represented in NOA and the cost of debt and the bondholder-shareholder conflicts? And if any what its direction?

In this regard, $\mathrm{Li}$ (2015) tries to identify the association between bondholder/shareholder conflicts over dividend policy and AC revealing more bondholder/shareholder conflicts encourage more conservatism to decrease cost of debt.

This bulk of literature confirms that a relationship direction between $\mathrm{AC}$ and the cost of debt vary with the varying of the country effects which is refer to a research gap must be filled. In addition, it focuses on the effect of CC neglecting the UCC considering the negative relationship between conditional and UCC postulate can't be altered which also refer to a research gap must be filled. Besides, the majority of these studies focus on the cost of debt as a dependent variable without showing the effect of the bondholder-shareholder conflicts on the UCC which also refer to a research gap must be filled.

Extending this line of literature, I conclude that the research gap is analyzing the relationship among UCC and the both cost of debt and bondholder-shareholder conflicts in a new environment neglecting the cost of debt financing which is the Iraqi accounting environment. Consequently, this study will contribute to the accounting literature by two ways; the first one to my best knowledge, it provides good evidence about the relationship direction in a new environment neglecting the debt financing cost this environment is Iraq. The second one, it focuses on the role of UCC rather than conditional conservatism.
Hypothesis development: Agency theory not only explains the conflict between managers and shareholders but also refers to inevitable conflict between bondholders and shareholders. These conflicts must be mitigated for the benefit of all parties on the perspective of efficient contracting theory (Jensen and Meckling, 1976).

In this regard, shareholders need higher dividends and bondholders need higher interest rates for meeting risks but achieving the desires of two parties may be impossible. Whereas bondholders wants to restrict dividend policy in their contracts and shareholders refuse these restrictions which may cause transferring wealth from bondholders to shareholders and increasing default risk to the bondholders (Black, 1976; Smith and Warner 1979; El-Gazzar andPastena, 1990, 1991; Healy and Palepu, 1990; Leftwich, 1983; Kalay, 1982).

On the other side, conservatism is a principle requires minimizing earnings, so, it represents a good mechanism for restricting dividends and lowing payments to the shareholders. By this way, bondholders will demand more conservative accounting and the manager's response to this demand will depend on the conservatism cost, i.e., depend on its probability to conflict with the profitability targets (Zhang, 2008).

Consequently, I expect if the firm management need this debt financing for achieving the profitability targets, it will agree with the desires of creditors by restricting dividend policy. In the same time, this conservative earning will fulfill the shareholders needs and profitability targets. So, using AC under these circumstances will mitigate the bondholders-shareholders conflicts. This leads to my first alternative hypothesis as follow.

- $\mathrm{H}_{1}$ : there is a positive relationship between $\mathrm{AC}$ and bondholders-shareholders conflicts, i.e., increasing bondholders-shareholders conflicts will lead to higher levels of AC

The creditor's demand on the conservative accounting resulting from the willingness to minimize the probability of occurrence default risk in return the creditors may accept lower rate of return (Li, 2015; Zhang, 2008). This show a negative relationship between $A C$ and the cost of debt but the effectiveness of this relationship will depend on the environment and its legal requirements (Daske et al., 2008; Christensen et al., 2013). So, I expect it's important to analyze this relationship on Iraq because it doesn't consider the cost of debt.

In another vein, prior literatures have found negative relationships between conditional and UCC which represented in NOA (Watts, 2003; Ball and 
Shivakumar, 2005). So, I expect positive relationship between UCC represented in NOA and the cost of debt because the increasing NOA which means decreasing UCC may increase the earnings which means increasing dividends and increasing risk to the bondholder thus increase the rate of return required by creditors and increase the bondholder-shareholder conflicts. This leads to my second alternative hypothesis as follow:

- $\mathrm{H}_{2}$ : there is a positive relationship between unconditional $\mathrm{AC}$ represented in NOA and the cost of debt, i.e., decreasing NOA will lead to decreasing the cost of debt

\section{MATERIALS AND METHODS}

Data and research design: For testing hypothesis I will try to show how tom measure variables and sample selection in this study as follow.

Measuring unconditional AC: I will follow Gilvoly and Hayn (2000) by using NOA for measuring UCC as follow:

Total accruals $=($ Net income + Depreciation $)-$

Cash flow from operations

Operating accruals $=$ Change on the debt balance +

Change on inventory+Change on the prepaid expenses-

Change on the credit balance-Change on taxes

NOA $=$ Total accruals-Operating accruals

Measuring the bondholders-shareholders conflicts: To measure the bondholders-shareholders conflicts the researcher will follow ( $\mathrm{Li}, 2015$; Zhang, 2008) by defining four attributes of the firm these attributes are:

Operating uncertainty: Refers to all cases imply uncertainty about future sales or prices which leads to volatility on earnings and higher risk for creditors which means increasing demand for conservatism. This indicates a negative relationship between earnings volatility that can be measured by the standard deviation of Return on Assets (ROA) and NOA which means positive relationship between UCC and operating uncertainty.

Dividend policy: Higher dividends may harm the bondholders by transferring wealth to shareholders and increase the probability of default risk which lead creditors to demand more conservatism. This means a negative relationship between the ratio of common dividends to total assets and NOA which indicates positive relationship between UCC and dividends.
Table 1: Sample distribution in Iraq Stock Market

\begin{tabular}{lrrr}
\hline Sectors & 2016 & 2017 & Total \\
\hline Banks & 18 & 18 & 36 \\
Insurance & 2 & 2 & 4 \\
Financial services & 5 & 3 & 8 \\
Services & 2 & 6 & 8 \\
Industries & 12 & 14 & 26 \\
Hotels and tourism & 4 & 8 & 12 \\
Agriculture & 2 & 4 & 6 \\
Communocationns & 1 & 3 & 4 \\
Financial transfer & 5 & 13 & 18 \\
Total & 51 & 71 & 122 \\
\hline
\end{tabular}

Leverage: Refers to the ratio of long term debt to total assets and higher leverage will lead to more conservative accounting. This indicates a negative relationship between leverage and NOA which indicates positive relationship between $\mathrm{UCC}$ and leverage.

Fixed asset intensity: It's difficult to liquidate fixed assets which represent a guarantee for the creditors, so, higher rate of property, plant and equipment to total assets leads to less demand on the conservatism for the creditors. This indicates a positive relationship between fixed assets intensity and NOA which indicates negative relationship between UCC and fixed assets intensity.

Measuring the cost of debt: I will follow Beatty et al. (2008) and Zhang (2008) by using 1 year ahead average interest rate as measure for the cost of debt which can be calculated by divided interest expenses by the average of debts for the current year and last year.

Sample selection: I will depend on the Iraq Stock Market for the period 2016-2017 for conducting this research depending on 236 firm-year observations. By excluding 87 missing values for observations to the variables existing in the multi regression and by excluding 27 observations related to firms have been written off from the Iraq Stock Exchange on 2017. So, my final sample will consist of 122 firm year observations can be presented in this Table 1 as follow.

Empirical models: This study aims to test the relationship between UCC and the bondholders-shareholders conflicts and testing the relationship between UCC and the cost of debt. So, I will employ these empirical models as follow.

Empirical model for testing $\mathbf{H}_{1}$ : The first hypothesis predicts that more conflict between bondholders and shareholders increase the demand for $\mathrm{AC}$, so, for testing $\mathrm{H}_{1} \mathrm{I}$ can run this empirical model:

$$
\begin{aligned}
& \text { Cons }=\beta 0+\beta 1 V_{-} R O A+\beta 2 \text { Div_ratio }+\beta 3 \text { Lev }+ \\
& \beta 4 \text { Intensity }+\varepsilon
\end{aligned}
$$


Table 2: Descriptive statistics

\begin{tabular}{llllll}
\hline Variables & Obs. & Mean & SD & Min. & Max. \\
\hline COD & 122 & 5461232 & 14200000 & 16724 & 93885093 \\
Cons & 122 & 67750.61 & 241809.9 & 29 & 1941375 \\
ROA & 122 & 0.1894074 & 0.1445728 & 0 & 0.933 \\
Size & 122 & 700845.6 & 375030 & 172038.6 & 1548347 \\
Lev & 122 & 3.157797 & 6.469371 & 0.17 & 52.15 \\
V_ROA & 122 & 3.00362 & 13.52971 & 0 & 142.825 \\
Div_Ratio & 122 & 0.0729324 & 0.165603 & 0 & 0.905913 \\
Intensity & 122 & 0.4481148 & 0.239791 & 0.11 & 0.99 \\
\hline
\end{tabular}

Where:

Cons $=$ NOA as a proxy for the UCC

$\mathrm{V}$ ROA $=$ Standard deviation for ROA

Div_ratio $=$ Common dividends divided by total assets

Lev $\quad=$ Long term debt divided by total assets

Intensity $=$ Property, plant and equipment divided by total assets

In this model, I expect positive signals for coefficients $\beta 1-\beta 3$ and negative signal for coefficient $\beta 4$.

Empirical model for testing $\mathbf{H}_{2}$ : The second hypothesis predicts that increasing $\mathrm{AC}$ lead to decreasing the cost of debt, so, for testing $\mathrm{H}_{2} \mathrm{I}$ can run this empirical model:

$$
\mathrm{COD}=\beta 0+\beta 1 \text { cons }+\beta 2 \text { size }+\beta 3 \mathrm{Lev}+\beta 4 \mathrm{ROA}+\varepsilon
$$

Where:

$\mathrm{COD}=$ Interest expenses divided by the average of debts for the current year and last year

Size $=$ Natural log of total assets

$\mathrm{ROA}=$ Return on assets and all other variables are as defined above

In this model, I expect positive signal for coefficient $\beta 1$ and control some attributes related to the firm represented in leverage, size and return on assets.

Empirical results: In this study, I will show the descriptive statistics for all the variables and the results of regression analysis resulting from running models (Beatty et al., 2008; Zhang, 2008) as follow.

First: descriptive statistics: Table 2 represents descriptive statistics for the Iraqi sample from 2016-2017 period. As shown in this the mean of the cost of debt is 5461232 which indicate relatively high cost of debt in the Iraq Stock Exchange. On the other side, the mean of NOA is 67750 which indicate relatively low NOA and high unconditional AC. This result confirm that Iraq Stock Exchange has a great volume of debt as well as this result also confirm that increasing the cost of debt lead to increasing unconditional $\mathrm{AC}$.
Table 3: Results of regression analy sis

\begin{tabular}{llcclcc}
\hline \multicolumn{5}{c}{ Dependent variable-AC (A) } & Dependent variable-cost of debt (B) \\
Variables & Coef. & t-stat & p-values & Coef. & t-stat & p-values \\
\hline Constant & 44031.14 & 1.05 & 0.297 & 9764367 & 3.27 & 0.001 \\
V_ROA & 11346.73 & 9.26 & 0.000 & & & \\
Div_Ratio & 261149.9 & 2.47 & 0.015 & & & \\
Lev & -189.6955 & -0.07 & 0.942 & & & \\
Intensity & -64625.05 & -0.87 & 0.388 & & & \\
Cons & & & & 25.47811 & 5.22 & 0.000 \\
Size & & & & -9.259683 & -2.90 & 0.004 \\
Lev & & & & 8510.242 & 0.04 & 0.966 \\
ROA & & & & 3006814 & 0.33 & 0.739 \\
N & 122 & & & 122 & & \\
Adj.R ${ }^{2}$ & 0.4610 & & & 0.2592 & & \\
\hline
\end{tabular}

The standard deviation of 14200000 for the cost of debt indicates that the sample suffer from a great variation in the cost of debt which means the creditors have a great role on the Iraq Stock Exchange in addition great variation in the debt covenants.

In another vein, the means of leverage, violation ROA and dividend ratio are $3.15,3,7.2 \%$, respectively, compared to $0.232,0.030,1.6 \%$, respectively by Li (2015). In addition, standard deviations of leverage, violation ROA and Dividend ratio are $6.47,13.53,16.56 \%$, respectively, compared to $0.1470 .041,1.8 \%$, respectively by Li (2015). These results may be relatively higher on the Iraq Stock Exchange which confirms a great conflict between the bondholder and shareholders.

Second; Hypothesis tests: As shown in the Table 3 above, in panel A the coefficients of $\mathrm{V}$ ROA and Div_ratio have a positive signal and it's significantly at the level of confidence $95 \%$. In addition the coefficients of Lev and intensity have a negative signal and it's not significantly at the level of confidence $95 \%$. These results mean the existence of the positive relationship between $\mathrm{AC}$ and the debtholders/shareholders conflicts, i.e., increasing standard deviations of the return on assets as a proxy of operating uncertainty and dividends ratio leads to increase the NOA as a proxy for UCC. This means that the Iraqi firms listed on stock exchange depend on accruals to achieve the profitability targets to the shareholders which lead to conflict between debtholders and shareholders and increase the demand of debtholders on more conservative accounting. This result confirms the first hypothesis of this study, so, I can accept the first alternative hypothesis of this study.

As shown in the Table 3 above in panel $B$ the coefficient of Cons, Lev and ROA hav a positive signal and it's significantly at the level of confidence $95 \%$ for conservatism only and not significant for both Lev and ROA. In addition the coefficient of size has a negative signal and its significantly at the level of confidence $95 \%$. This means existence of the positive relationship 
between NOA and the cost of debt and negative relationship between firm size represented in total assets and the cost of debt, i.e., increasing the $\mathrm{AC}$ by minimizing the accruals leads to lower cost of debt and increasing total assets as guarantee for the creditors leads to lower cost of debt.

This means that the Iraqi firms listed on stock exchange seek to minimize the cost of debt by minimizing NOA (Increase unconditional AC) as well as the creditors depend on the total assets as a guarantee for minimizing risks and accept lower interest rates. This result confirms the second hypothesis of this study, so, I can accept the second alternative hypothesis of this study.

\section{CONCLUSION}

This study aims to investigate the tradeoff between $\mathrm{AC}$ and the cost of debt by examining two relationships. The first relationship examines the Zeffect of debtholders/shareholders conflicts on the level of unconditional AC represented in NOA. The second relationship examines the effect of unconditional $\mathrm{AC}$ represented in NOA on the cost of debt. This study tried to examine these relationships using a sample of $122 \mathrm{firm}$ year observations to the period 2016-2017 on the Iraq Stock Exchange.

This study found positive relationship between $\mathrm{AC}$ and the debtholders/shareholders conflicts, i.e., increasing standard deviations of the return on assets as a proxy of operating uncertainty and dividends ratio leads to increase the NOA as a proxy for UCC. In addition, found positive relationship between NOA and the cost of debt and negative relationship between firm size represented in total assets and the cost of debt, i.e., increasing the $\mathrm{AC}$ by minimizing the accruals leads to lower cost of debt and increasing total assets as guarantee for the creditors leads to lower cost of debt.

These results mean that the Iraqi firms listed on stock exchange depend on accruals to achieve the profitability targets to the shareholders which lead to conflict between debtholders and shareholders and increase the demand of debtholders on more conservative accounting. On the other side, Iraqi firms listed on stock exchange seek to minimize the cost of debt by minimizing NOA (Increase unconditional $\mathrm{AC}$ ) as well as the creditors depend on the total assets as a guarantee for minimizing risks and accept lower interest rates.

\section{REFERENCES}

Ahmed, A., B. Billings, R. Mort and M. Stanford-Harris, 2002. The role of accounting conservatism in mitigating bondholder-shareholder conflicts over dividend policy and in reducing debt costs. Account. Rev., 77: 867-890.
Ahmed, A.S. and S. Duellman, 2011. Evidence on the role of accounting conservatism in monitoring managers investment decisions. Account. Finance, 51: 609-633.

Ball, R. and L. Shivakumar, 2005. Earnings quality in UK private firms: Comparative loss recognition timeliness. J. Account. Econ., 39: 83-128.

Ball, R., 2001. Infrastructure requirements for an economically efficient system of public financial reporting and disclosure. Brookings-Wharton Pap. Financial Serv., 2001: 127-169.

Ball, R., A. Robin and G. Sadka, 2008. Is financial reporting shaped by equity markets or by debt markets? An international study of timeliness and conservatism. Rev. Account. Stud., 13: 168-205.

Basu, S., 1997. The conservatism principle and the asymmetric timeliness of earnings. J. Account. Econ., 24: 3-37.

Basu, S., 2005. Discussion of conditional and unconditional conservatism: Concepts and modeling. Rev. Account. Stud., 10: 311-321.

Beatty, A., J. Weber and J.J. Yu, 2008. Conservatism and Debt. J. Account. Econ., 45: 154-174.

Beaver, W.H. and S.G. Ryan, 2005. Conditional and unconditional conservatism: Concepts and modeling. Rev. Account. Stud., 10: 269-309.

Black, F., 1976. The dividend puzzle. J. Portfolio Manage., 2: $5-8$.

Christensen, H.B., L. Hail and C. Leuz, 2013. Mandatory IFRS reporting and changes in enforcement. J. Account. Econ., 56: 147-177.

Daske, H., L. Hail, C. Leuz and R. Verdi, 2008. Mandatory IFRS reporting around the world: Early evidence on the economic consequences. J. Acc. Res., 46: 1085-1142.

El-Gazzar, S. and V. Pastena, 1990. Negotiated accounting rules in private financial contracts. J. Account. Econ., 12: 381-396.

El-Gazzar, S. and V. Pastena, 1991. Factors affecting the scope and initial tightness of covenant restrictions in private lending agreements. Contemp. Account. Res., 8: 132-151.

Francis, J.R. and X. Martin, 2010. Acquisition profitability and timely loss recognition. J. Account. Econ., 49: 161-178.

Givoly, D. and C. Hayn, 2000. The Changing time-series properties of earnings, cash flows and accruals: Has financial reporting become more conservative. J. Account. Econ., 29: 287-320.

Healy, P.M. and K.G. Palepu, 1990. Effectiveness of accounting-based dividend covenants. J. Account. Econ., 12: 97-123.

Jensen, M.C. and W.H. Meckling, 1976. Theory of the firm: Managerial behavior, agency costs and ownership structure. J. Financial Econ., 3: 305-360. 
Kalay, A., 1982. Stockholder-bondholder conflict and dividend constraints. J. Financial Econ., 10: 211-233.

Lara, J.M.G., B.G. Osma and F. Penalva, 2011. Conditional conservatism and cost of capital. Rev. Accounting Stud., 16: 247-271.

Lara, J.M.G., B.G. Osma and F. Penalva, 2016. Accounting conservatism and firm investment efficiency. J. Accounting Econ., 61: 221-238.

Leftwich, R., 1983. Accounting information in private markets: Evidence from private lending agreements. Account. Rev., 58: 23-42.

Li, X., 2015. Accounting conservatism and the cost of capital: An international analysis. J. Bus. Finance Account., 42: 555-582.
Pae, J., 2007. Unexpected accruals and conditional accounting conservatism. J. Bus. Finance Account., 34: $681-704$.

Rodrigues, S.D.S. and F.C. Galdi, 2017. Investor relations and information asymmetry. Rev. Contab. Finanças, 28: 297-312.

Smith Jr, C.W. and J.B. Warner, 1979. On financial contracting: An analysis of bond covenants. J. Financial Econ., 7: 117-161.

Watts, R.L., 2003. Conservatism in accounting part II: Evidence and research opportunities. Account. Horizons, 17: 287-301.

Zhang, J., 2008. The contracting benefits of accounting conservatism to lenders and borrowers. J. Accounting Econ., 45: 27-54. 